\title{
MEKANISME TATA KELOLA PERUSAHAAN, PERSAINGAN PASAR PRODUK DAN KINERJA PERUSAHAAN
}

\author{
Ika Pratiwi ${ }^{1}$, \\ Retno Dwi Irianto ${ }^{2}$. \\ ${ }^{1}$ Sekolah Vokasi, Universitas Diponegoro \\ Email: ikapratiwi@lecturer.undip.ac.id \\ ${ }^{2}$ Sekolah Vokasi, Universitas Diponegoro \\ Email: retnodwiirianto@lecturer.undip.ac.id
}

\begin{abstract}
The board of directors represents the interests of shareholders and monitors management on a wide range of agency matters. Board independence remains an important aspect of board monitoring among regulators worldwide. Several theoretical studies investigate the effect of corporate governance and some effects of competition on firm performance but the aim of this study is to examine the effect of corporate governance mechanisms on firm performance and to examine the effect of interaction between corporate governance mechanisms and product market competition on firm performance. The population in this study are all companies listed on the Indonesia Stock Exchange in 2017-2019. The variables of corporate governance mechanisms used in this study are independent commissioners and managerial ownership and product market competition as moderating variables. The sampling method in this study was purposive sampling. The company criteria used are companies listed on the IDX in 2017-2019 except for the financial sector. There are 711 data that fall into the criteria. Multiple regression analysis and moderate regression analysis (MRA) were used as analysis techniques. The results showed that independent commissioners had no effect on company performance, while managerial ownership had a positive effect on company performance. The results of the interaction effect of corporate governance mechanisms and product market competition on company performance indicate that product market competition has a significant positive effect on the relationship between independent commissioners and company performance. Product market competition has a significant positive effect on the relationship between managerial ownership and company performance on company performance.
\end{abstract}

Keywords: Firm Performance, Independent Commissioner, Managerial Ownership, Product Market Competition

\section{PENDAHULUAN}

Menurut Mohan \& S. Chandramohan (2018) tujuan utama perusahaan didirikan yaitu meningkatkan kesejahteraan pemegang saham yang dapat ditingkatkan dengan adanya kinerja perusahaan yang baik. Efisiensi dan efektifitas perusahaan yang dilakukan manajemen dalam mencapai target yang ditetapkan oleh perusahaan tercermin dalam kinerja perusahaan. Hal ini dapat dinilai dengan menganalisis rasio keuangan pada laporan keuangan perusahaan pada periode tertentu untuk mengetahui kondisi perusahaan dan posisi perusahaan ditengah perusahaan lain dan bermanfaat bagi para investor dan pemakai laporan keuangan dalam pengambilan keputusan. Jadi untuk menganalisa kondisi keuangan suatu perusahaan, salah satu faktor utama yang diperhatikan khusus oleh para investor dan pemakai laporan keuangan pada umumnya yaitu profitabilitas perusahaan. Di Indonesia, kinerja dari perusahaan-perusahaan go public pada tahun 2019, Bursa Efek Indonesia (BEI) mencatat total laba bersih perusahaan terbuka per Maret 2019 mengalami peningkatan sebesar 8,86\% menjadi Rp 96,84 triliun dari Rp 88,96 triliun per Maret 2018. Padahal total pendapatan perusahaan-perusahaan tersebut hanya tumbuh 4,13\% menjadi Rp 866,1 triliun dari Rp 831,76 triliun.

Menurut Liu, Qu, \& Haman (2018), pelaksanaan tata kelola perusahaan diterapkan agar pengelolaan perusahaan dapat dilaksanakan sesuai dengan kepentingan dari pemilik perusahaan. Adanya kesejajaran kepentingan mengurangi konflik kepentingan antara pihak pemilik dan pengelola perusahaan sehingga dapat mengurangi biaya agensi yang dikeluarkan perusahaan yang pada akhirnya akan berdampak pada peningkatan kinerja (Moradi, Bagherpour Velashani, \& Omidfar, 2017). Menurut Singla \& Singh (2019) dalam pelaksanaannya, suatu tata kelola yang ada dalam perusahaan tidak selalu dapat dilaksanakan secara efektif guna mencapai tujuan perusahaan. Hal ini disebabkan oleh faktor- 
faktor seperti struktur dewan (komisaris independen) dan kepemilikan (salah satunya yaitu kepemilikan manajerial) yang merupakan bagian dari mekanisme tata kelola, dapat mempengaruhi bagaimana suatu perusahaan dikelola dan dikendalikan.

Dewan komisaris harus memiliki sejumlah dewan yang tidak terlibat (bersifat independen) di dalam manajemen, yang dapat membuat keputusan secara independen (Singla \& Singh, 2019). Manajemen yang memiliki posisi sebagai pengelola perusahaan juga sekaligus pemilik perusahaan akan merasa bahwa kepentingan atau pencapaian yang diharapkan investor dapat selaras dengan kepentingan manajemen. Menurut Moradi, Bagherpour Velashani, \& Omidfar (2017) pihak manajemen yang diberikan kesempatan dalam kepemilikan saham perusahaan dapat memotivasi manajemen mempertanggungjawabkan setiap keputusan yang diambilnya sehingga menjadikan manajamen menjadi lebih berhati-hati dalam mengelola perusahaan .

Menurut Liu, Qu, \& Haman (2018) Kinerja perusahaan merupakan konsekuensi match atau fit atau kepasan antara dua atau lebih faktor. Berbagai faktor ini diantaranya yaitu faktor eksternal lingkungan. Dalam studi yang telah ada dinyatakan bahwa kepemilikan manajerial dan adanya komisaris independen memiliki pengaruh positif signifikan terhadap peningkatan kinerja. Adapun penelitian Arora \& Sharma (2016), Azeez (2015), Moradi, Bagherpour Velashani, \& Omidfar (2017) menunjukkan hasil yang berbeda. Menurut Moradi, Bagherpour Velashani, \& Omidfar (2017) hubungan antara mekanisme tata kelola perusahaan dan kinerja tidak secara langsung demikian karena terdapat faktor kontekstual lain yang ada dalam hubungan diantara kedua faktor tersebut. Faktor tersebut adalah persaingan pasar produk. Pemilihan variabel persaingan pasar produk didasarkan pada dasar teori kontingensi yang menyatakan hubungan dua atau lebih faktor sangat bergantung pada faktor lainnya (kontinguen) yang tidak bisa dikendalikan oleh suatu organisasi. Semakin match/fit hubungan mekanisme tata kelola perusahaan dan persaingan pasar produk, maka semakin tinggi kinerja yang dicapai oleh sebuah perusahaan (Liu et al., 2018). Argumentasi ini diperkuat oleh pandangan bahwa lingkungan adalah faktor kontekstual terpenting yang memiliki dampak sangat kuat pada arah strategi suatu perusahaan. Persaingan pasar produk merupakan salah satu faktor yang terkait dengan lingkungan industri perusahaan, yang secara langsung mempengaruhi perusahaan dan tindakan kompetitifnya. Oleh karena itu, penelitian ini menduga bahwa hubungan mekanisme tata kelola perusahaan dengan kinerja perusahaan secara keseluruhan tergantung bagaimana mekanisme tata kelola perusahaan tersebut berada pada kondisi persaingan yang dihadapi. Menurut Moradi, Bagherpour Velashani, \& Omidfar (2017) para Ekonom berpendapat direksi yang berada dalam industri yang kompetitif mempunyai insentif yang kuat dalam bersaing dengan cara mengurangi ketidakefisiensi penggunaan sumber daya. Oleh karena itu, ada sedikit kebutuhan untuk memotivasi para direksi dan dewan komisaris melalui penguatan metode tata kelola perusahaan. Persaingan pasar produk mempunyai pengaruh mendisiplinkan peran direksi sebagai pihak yang mengelola perusahaan dan mendorong dewan komisaris untuk menjalankan fungsi pengawasannya secara optimal.

Dalam penelitian ini, rumusan masalah berdasarkan uraian yang telah dijelaskan pada latar belakang masalah di atas, yaitu apakah:

1. Komisaris independen mempunyai pengaruh positif signifikan terhadap kinerja perusahaan.

2. Kepemilikan manajerial mempunyai pengaruh positif signifikan terhadap kinerja perusahaan.

3. Persaingan pasar produk mempunyai pengaruh signifikan terhadap hubungan komisaris independen dan kinerja perusahaan.

4. Apakah persaingan pasar produk mempunyai pengaruh signifikan terhadap hubungan kepemilikan manajerial dan kinerja perusahaan?

\section{KAJIAN PUSTAKA DAN PEGEMBANGAN HIPOTESIS}

\section{Teori Agensi}

Untuk memahami tata kelola perusahaan digunakan perspektif hubungan keagenan karena membahas konflik hubungan antara prinsipal (pemilik perusahaan) dan agen (manajer perusahaan). Teori agensi memiliki asumsi bahwa agen dan prinsipal mempunyai kepentingan yang berbeda atau masing-masing (self interest). Kepentingan diantara keduanya tersebut lebih banyak mengalami perbedaan. Menurut Sarpong-Danquah, Gyimah, Afriyie, \& Asiama (2018) konflik agensi ini muncul karena Prinsipal dan agen masing-masing ingin memaksimalkan keuntungan sehingga muncul perselisihan. Adanya konflik keagenan tersebut mengharuskan prinsipal mengendalikan dan 
mengawasi perilaku agen dalam menjalankan tugasnya agar sesuai dengan tujuan yang diharapkan prinsipal (Singla \& Singh, 2019).

Menurut Arora \& Sharma (2016) pemisahan kepemilikan dan pengendalian terjadi dalam suatu perusahaan menyebabkan para pemegang saham tidak aktif secara langsung teribat dalam manajemen perusahaan. Namun ada manfaat adanya pemisahan kepemilikan dan pengendalian yang memungkinkan adanya perubahan kepemilikan perusahaan tanpa harus memengaruhi kegiatan rutin dari perusahaan. Akan tetapi kelemahan yang timbul adanya masalah keagenan. Menurut Moradi, Bagherpour Velashani, \& Omidfar (2017) mekanisme tata kelola perusahaan adalah alat pengawasan yang dapat memfasilitasi kesejajaran kepentingan diantara pemegang saham dengan manajemen. Penyejajaran kepentingan kedua pihak tersebut akan mengurangi biaya agensi perusahaan dan tentunya akan meningkatkan kinerja perusahaan. Mekanisme tata kelola perusahaan dapat digunakan sebagai bentuk pengawasan terhadap manajemen perusahaan (Singla \& Singh, 2019).

\section{Teori Kontingensi}

Teori kontingensi menyatakan bahwa tidak ada cara terbaik dalam mencapai kesesuaian antara faktor organisasi dan lingkungan dalam memperoleh prestasi yang baik bagi suatu organisasi (Venkatraman, 1989). Dalam teori kontinjensi, kinerja sebuah organisasi selalu dipengaruhi oleh variabel kesesuaian antara variabel utama dengan variabel lain, atau sering disebut fit, terhadap kinerja. Secara konseptualisasi, suatu strategi dalam hal ini mekanisme tata kelola perusahaan tidak ada yang unggul, terlepas dari konteks lingkungan atau organisasi, fit as moderation telah umum digunakan pada perspektif kontingensi Venkatraman yang dioperasionalkan dalam perspektif (interaksi) suatu moderasi. Menurut Liu, Qu, \& Haman (2018), perspektif moderasi, pengaruh variabel independen pada variabel dependen bergantung pada tingkat variabel ketiga yang disebut sebagai moderator/moderasi. Perspektif ini menetapkan pada teori yang mendasari bahwa pengaruh dari prediktor atau independen (mekanisme tata keloa perusahaan) bervariasi diberbagai tingkat moderator (persaingan pasar produk). Teori kontingensi menjelaskan agar mekanisme tata kelola perusahaan dapat efektif maka harus konsisten dengan aspek lain dari organisasi dan /atau lingkungan eksternal (persaingan pasar produk).

\section{Hipotesis Penelitian}

Menurut Moradi, Bagherpour Velashani, \& Omidfar (2017), dalam teori teori agensi, pemisahan kepemilikan dan pengendalian menimbulkan masalah keagenan karena kedua belah pihak memiliki kepentingan masing-masing dalam memaksimalkan keuntungannya. Penyejajaran kepentingan tersebut dicapai dengan adaya komisaris independenyang merupakan bagian dari mekanisme tata kelola perusahaan. Menurut KNKG (2006) komisaris independen merupakan dewan komisaris yang tidak terafiliasi dengan direksi, anggota komisaris lainnya dan dan pemegang saham pengendali serta bebas dari hubungan bisnis serta hubungan lainnya dan bertugas sebagai badan pengawas terkait kebijakan, pengurusan perusahaan dan pemberi nasihat direksi.

Pengawasan yang ketat, saran, keahlian di bidang keuangan, hukum dan lainnya yang dimiliki oleh komisaris independen berpengaruh positif terhadap kinerja perusahaan. Peningkatan jumlah dari komisaris independen dalam suatu perusahaan maka perusahaan tersebut cenderung memiliki kinerja yang lebih baik karena dapat bekerja tanpa tekanan dari pihak manapun. Direksi berdasarkan status mereka memiliki banyak informasi, kemungkinan akan berkolusi dengan manajer serta membuat keputusan yang bertentangan dengan kepentingan atau kesejahteraan pemegang saham. Komisaris independen yang melakukan pengawasan terhadap kinerja manajemen berada dalam posisi netral. Hal ini dapat membantu menghilangkan masalah agensi antara prinsipal dan agen karena dapat dipastikan bahwa manajemen bekerja dan mengambil keputusan sesuai dengan kepentingan pemegang saham (Sarpong-Danquah et al., 2018). Keberadaan komisaris independen menjadi optimal di dalam persahaan ketika perusahaan membutuhkan nasihat mengenai metode atau strategi baru dalam menjalankan perusahaan, hal ini nantinya akan berdampak pada peningkatan kinerja perusahaan. Pada akhirnya hal tersebut mampu memberikan tuntutan kepada manajemen untuk mencapai kinerja perusahaan yang tinggi.

Menurut Moradi, Bagherpour Velashani, \& Omidfar (2017) adanya Proporsi yang lebih tinggi dari komisaris independen menjadikan perilaku dewan dapat dipantau dengan lebih baik, yang nantinya meningkatkan kinerja perusahaan. Sarpong-Danquah (2018) menemukan bukti bahwa proporsi komisaris independen lebih tinggi mengarah pada pengawasan yang lebih efektif. Arora \& Sharma 
(2016) dan Singla \& Singh (2019) menunjukkan hasil yang berbeda, komisaris independen berpengaruh negatif terhadap kinerja perusahaan. Adapun penelitian Mardnly (2018) menunjukkan komisaris independen tidak berpengaruh terhadap kinerja perusahaan. Namun penelitian Moradi, Bagherpour Velashani, \& Omidfar (2017), Liu, Qu, \& Haman (2018) dan Danquah, dkk, (2018) menemukan bukti bahwa independensi dewan komisaris berpengaruh positif terhadap kinerja perusahaan. Berdasarkan uraian di atas, hipotesis yang dirumuskan yaitu:

\section{H1: Komisaris independen mempunyai pengaruh positif signifikan terhadap kinerja perusahaan}

Manajemen yang memiliki posisi sebagai pemegang saham atau saham yang dimiliki oleh manajemen perusahaaan dapat disebut kepemilikan manajerial. Kepemilikan manajerial adalah satu diantara mekanisme yang dapat digunakan dengan tujuan agar pengelola perusahaan melaksanakanaktivitas pengelolaan perusahaan sesuai dengan kepentingan pemilik perusahaan (Moradi et al., 2017). Adanya kepemilikan manajerial yang tinggi dapat digunakan sebagai cara untuk mengatasi masalah keagenan. Sebagai manajemen sekaligus pemegang saham, Manajer akan termotivasi dalam memaksimalkan kinerjanya dimana hal ini merupakan keinginan dari para pemegang saham (Arora \& Sharma, 2016). Kepemilikan manajerial akan membantu mensejajarkan kepentingan dari pihak-pihak yang berkepentingan (Farooque, 2019). Kepemilikan saham yang dimiliki manajemen menjadikan manajemen merasa pencapaian dan kepentingan investor dapat selaras dengan kepentingan pribadinya.

Adanya rasa kepemilikan perusahaan menjadikan manajemen merasa menanggung konsekuensi dari keputusan yang diambil sehingga menjadikan mereka lebih berhati-hati dalam pengelolaan perusahaan (Farooque, 2019). Adanya kepemilikan manajerial menjadikan manajemen mengambil keputusan dan bertindak untuk meningkatkan kesejahteraan pemegang saham. Adanya rasa kepemilikan perusahaan menjadikan manajemen ikut merasa bertanggung jawab pada konsekuensi keputusan yang dibuat (Moradi et al., 2017). Hal ini menjadikan manajemen lebih berhati-hati dalam mengelola perusahaan. Hasil penelitian Mardnly (2018) juga menunjukkan bahwa semakin tinggi tingkat kepemilikan manajerial maka kinerja perusahaan juga semakin meningkat. Berdasarkan pada uraian diatas, penelitian ini merumuskan hipotesis sebagai berikut:

\section{H2: Kepemilikan manajerial mempunyai pengaruh positif signifikan terhadap kinerja perusahaan}

Hasil penelitian terkait komisaris independen dan kinerja perusahaan menunjukkan hasil yang tidak konsisten (Moradi et al., 2017). Penyebabnya terjadi karena masih terdapat faktor lain yang dapat memperkuat efektifitas mekanisme tata kelola perusahaan yaitu persaingan pasar produk. Persaingan pasar produk merupakan faktor lain yang memoderasi hubungan dua faktor (mekanisme tata kelola perusahaan dan kinerja perusahaan). Lingkungan merupakan faktor kontekstual yang paling penting yang berpengaruh sangat kuat terhadap arah strategi perusahaan (Moradi et al., 2017). Dalam penelitianpenelitian sebelumnya diketahui bahwa persaingan pasar produk merupakan faktor kunci dalam mencapai kinerja perusahaan yang optimal (Singla \& Singh, 2019). Menurut teori kontingensi tidak ada cara terbaik dalam mencapai kesesuaian antara faktor organisasi dan lingkungan untuk memperoleh prestasi yang baik bagi suatu organisasi. Kinerja perusahaan merupakan konsekuensi fit antara dua atau lebih faktor. Pada kondisi pasar yang kompetitif, kelangsungan hidup perusahaan jangka panjang bergantung terhadapapakah perusahaan mampu memenuhi standar yang lebih tinggi daripada rata-rata tata kelola perusahaan yang telah ditetapkan sebelumnya. Adanya independensi dewan komisaris melalui pembentukan komisaris independen sangat penting meningkatkan kekuatan dari dewan komisaris untuk mengawasi tugas dan tindakan yang diambil oleh direksi (Puni \& Anlesinya, 2020). Adanya persaingan yang ketat yang dihadapi perusahaan maka dibutuhkan pengawasan yang efektif dalam hal ini yaitu pengawasan dari dewan komisaris.

Dewan komisaris yang mampu mengawasi secara efektif dapat menjadikan manajemen perusahaan melaksanakan kinerja operasionalnya dengan lebih baik dan manajemen dituntut agar memperoleh kinerja perusahaan lebih tinggi. Berdasarkan hasil penelitian (Moradi et al., 2017) menemukan bahwa tingginya proporsi komisaris independen mengarah pada peningkatan kinerja yang lebih tinggi. Menurut Majeed, Yan, \& Tauni (2018) dalam kondisi persaingan yang tinggi, perusahaan yang tata kelola perusahaannya buruk kemungkinan digabung atau dilikuidasi meningkat, ini berdampak pada hilangnya nama baik manager dan hilangnya reputasi komisaris independen. Oleh karena itu, untuk menjaga reputasinya, Komisaris independen termotivasi lebih dalam mengawasi 
perilaku manager dalam mencapai kinerja manajer, yang nantinya akan meningkatkan kinerja perusahaan.

Perusahaan yang berada dalam suatu industri yang tingkat kompetensinya tinggi akan saling bersaing menjual produknya kepada konsumen dengan menyediakan produk yang sesuai selera konsumen yang beragam dan terkait penetapan harga jual. Persaingan mendorong perusahaan memaksimalkan pelaksanaan praktik tata kelola terutama terkait pengelolaan dan alokasi sumber daya yang dimiliki perusahaan agar perusahaan dapat beroperasi secara efisien dan efektif. Oleh karena itu, persaingan dapat memiliki pengaruh yang mendisiplinkan perilaku dan ketidakefektifan peran dari komisaris independen untuk melaksanakan fungsi pengawasannya secara optimal (Moradi et al., 2017). Direksi yang berada pada industri yang kompetitif memiliki insentif yang kuat untuk mengurangi ketidakefisiensi penggunaan sumber daya yang dimiliki. Dampak komisaris independen terhadap kinerja perusahaan lebih kuat ketika persaingan di pasar produk perusahaan ketat yang dilakukan melalui penguatan metode tata kelola perusahaa. Namun penelitian Mardnly (2018) menjelaskan bahwa persentase anggota dewan independen dengan kualitas pengungkapan tidak memiliki pengaruh dan persaingan pasar produk tidak meningkatkan ataupun memperkuat hubungan diantara variabel tersebut. Akan tetapi hasil penelitian Liu, Qu, \& Haman (2018) dan Moradi, Bagherpour Velashani, \& Omidfar (2017) menyatakan adanya pertumbuhan produktivitas yang lebih tinggi saat perusahaan beroperasi dalam situasi pasar persaingan yang lebih tinggi. Berdasarkan uraian tersebut diatas, penelitian ini merumuskan hipotesis sebagai berikut:

\section{H3: Persaingan pasar produk berpengaruh signifikan terhadap hubungan komisaris independen dan kinerja perusahaan}

Kepemilikan saham oleh manajemen dapat mempengaruhi bagaimana perusahaan dikelola dan dikendalikan. interaksi antara persaingan pasar produk dan mekanisme tata kelola perusahaanmembatasi kebijakan yang diambil manajemen dan siatuasi persaingan yang ada mendorong manajer memaksimalkan kinerjanya melalui efisiensi sumber daya. Persaingan yang tinggi berdampak pada adanya laba perusahaan yang berkurang sehingga mengurangi nilai pasar saham perusahaan. Hal ini dapat merupakan indikasi dapat terjadi pengambilalihan perusahaan sehingga memberi tekanan pada manajer agar menghasilkan kinerja lebih baik. Ketika perangkat tata kelola internal saling melengkapi pengaruh persaingan pasar produk akan lebih tinggi pada perusahaan yang memiliki struktur tata kelola yang efisien. Pengaruh substitusi ini menjelaskan saat tata kelola perusahaan lemah, Persaingan berperan penting sebagai perangkat pendisiplin yang memaksa manajer mengurangi kelonggaran manajerial dan meningkatkan kinerja (Moradi et al., 2017). Namun, apabilapersaingan dan tata kelola perusahaan hubungannya adalah pelengkap, faktor persaingan pasar produk mungkin tidak cukup dalam mengurangi ketidakefisiensi pengelolaan sumber daya pada lingkungan dengan tatakelola perusahaan yang buruk.

Menurut Liu, Qu, \& Haman (2018) persaingan dalam pasar produk perusahaan adalah kekuatan yang sangat berpengaruh untuk memastikan pelaksanaan tata kelola perusahaan yang baik. Bukti empiris menunjukkan persaingan mempunyai pengaruh positif terhadap produktivitas perusahaan. Saat dihadapkan pada tata kelola internal yang lemah, persaingan pasar produk yang tinggidapat memastikan bahwa manajemen tidak melalaikan tanggungjawabnya. Persaingan memberikan tolok ukur untuk mengukur kinerja manajemen. Persaingan pasar produk yang lebih tinggi memaksa manajemen mencapai kinerja yang tinggi jika tidak persaingan dapat menyebabkan kebangkrutandan perusahaan dilikuidasi. Adanya kemungkinan peningkatan kebangkrutan mendorong manager mengurangi biaya yang diperlukan untuk menghindari kebangkrutan. Terlebih, persaingan mempunyai implikasi pada reputasi yang parah karena kinerja perusahaan akan dibandingkan dengan rekan-rekannya, itu menempatkan banyak tekanan moral terhadap manager untuk mencapai kinerja perusahaan yang tinggi (Iqbal, Zhang, Tauni, \& Jebran, 2020).

Adanya mekanisme persaingan seperti yang diuraikan diatas, maka manajemen sebagai pengelola perusahaan dalam proses produksinya harus mengoptimalkan pengalokasian sumber daya yang dimiliki perusahaan agar dapat beroperasi secara efisien. Dalam situasi persaingan tersebut manajemen yang selaku pengelola juga sekaligus pemilik perusahaan akan terdorong untuk mengoptimalkan penerapan praktik tata kelola perusahaan untuk mencapai kinerja yang diharapkan. Oleh karena itu, persaingan dapat memiliki pengaruh yang mendisiplinkan perilaku dan ketidakefektifan peran dari manajemen dalam menjalankan fungsinya sebagai pihak yang mengelola perusahaan (Moradi et al., 2017). 
Kepemilikan manajerial terhadap kinerja perusahaan dampaknya lebih kuat ketika persaingan di pasar produk perusahaan ketat. Berdasarkan uraian tersebut diatas, penelitian ini merumuskan hipotesis bahwa:

\section{H4: Persaingan pasar produk berpengaruh signifikan terhadap hubungan kepemilikan manajerial dan kinerja perusahaan}

\section{METODE PENELITIAN}

Variabel dependen yang digunakan dalam penelitian ini adalah Kinerja Perusahaan, disimbolkan dengan KP. Kinerja Perusahaan diukur dengan Return on Equity (ROE) yang dihitung dengan membagi laba bersih setelah pajak atau laba tahun berjalan dengan total ekuitas perusahaan, dinyatakan dalam satuan persentase. Argumen mengenai penggunaan proksi tersebut didasarkan pada penelitian Moradi, Bagherpour Velashani, \& Omidfar (2017). ROE adalah pengukuran profitabilitas yang menunjukkan kemampuan perusahaan dalam menghasilkan laba yang berasal dari pendanaan pemegang saham. ROE memungkinkan pemegang saham mengetahui berapa banyak laba yang dihasilkan perusahaan dari setiap investasi mereka dalam perusahaan. ROE dipilih karena merupakan pengukuran kinerja keuangan berbasis akuntansi yang penting dan diterima secara luas. Kinerja perusahaan merupakan suatu alat ukur untuk menentukan nilai keberhasilan perusahaan dalam melakukan usahanya (Liu et al., 2018). Variabel moderasi dalam penelitian ini yaitu Persaingan Pasar Produk, disimbolkan dengan PPP, diukur dengan logaritma natural penjualan industry atau dapat dirumuskan dengan Market size $=\log \left(\sum \mathrm{S}_{i j}\right)$. Dimana $\mathrm{S}_{i j}$ mengindikasikan penjualan dari perusahaan i dalam industry j. Persaingan pasar produk adalah tingkat usaha yang dilakukan perusahaan untuk mencapai kesuksesan di antara pesaing mereka dalam industri. Variabel kinerja perusahaan memiliki kemungkinan untuk ditentukan oleh berbagai faktor. Dibawah ini merupakan variabel kontrol yang digunakan pada penelitian ini, yaitu (1) Ukuran perusahaan (SIZE) yang diukur dengan Log Total Aset, (2) Rasio lancar (LIQ) diukur dengan membagi aset lancar terhadap hutang lancar. Variabel independen dalam penelitian ini, yaitu Komisaris independen, disimbolkan dengan KI, diukur dengan jumlah komisaris independen dibagi dengan total anggota dewan komisaris, dinyatakan dalam satuan persentase. Komisaris independen adalah komisaris yang tidak berasal dari pihak yang memiliki hubungan bisnis dan kekeluargaan dengan pemegang saham pengendali, anggota direksi dan dengan anggota komisaris lainnya maupun dengan perusahaan itu sendiri (KNKG, 2006). Kepemilikan Manajerial, disimbolkan KEMANAJ yang merupakan kepemilikan saham oleh manajemen perusahaan yang diukur dengan persentase jumlah saham yang dimiliki oleh manajemen. Sampel diseleksi dengan menggunakan metode purposive sampling sehingga berdasarkan kriteria yaitu perusahaan yang terdaftar di Bursa Efek Indonesia tahun 2019, beroperasi dalam industri sector non keuangan, menerbitkan laporan laporan keuangan serta laporan tahunan pada periode yang berakhir tahun 2017, 2018 dan 2019 dan menerbitkan laporan keuangan menggunakan mata uang rupiah. Maka didapatkan sampel sebanyak 711 sampel penelitian.

\section{Metode Analisis}

Populasi penelitian adalah seluruh perusahaan yang terdaftar pada Bursa Efek Indonesa (BEI) pada tahun 2017-2019.Penelitian ini adalah jenis penelitian deskriptif kuantitatif. Metode Purposive Samplingdigunakan sebagai teknik pengambilan sampel dengan tujuan mendapatkan sampel penelitian yang sesuai dengan tujuan penelitian. Teknik analisis untuk menguji hipotesis dilakukan dengan menggunakan metode analisis regresi linier berganda, menggunakan program SPSS dan analisis uji interaksi variabel moderating, menggunakan MRA (moderate regression analysis) atau uji interaksi.

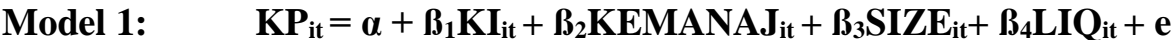

Model 1 adalah model untuk menguji hubungan antara komisaris independen, dan kepemilikan manajerial terhadap kinerja perusahaan.

\section{Model 2 : $\quad \mathrm{KP}_{\mathrm{it}}=\alpha+\beta_{1} \mathrm{KI}_{\mathrm{it}}+\beta_{2} \mathrm{KEMANAJ}_{\mathrm{it}}+\beta_{3} \mathbf{P P P}_{\mathrm{it}}+\beta_{4} \mathrm{KI}_{\mathrm{it}} \times \mathrm{PPP}_{\text {it }}+\beta_{3} \beta_{5} \mathrm{KEMANAJ}_{\text {it }}$ $\times P_{P P}+B_{6} S_{2} E_{i t}+B_{7} L_{L} Q_{i t}+e$}

Model 2 adalah model untuk menguji interaksi hubungan antara mekanisme tata kelola perusahaan, persaingan pasar produk dan kinerja perusahaan.

Keterangan :

$\mathrm{KP}_{\mathrm{it}}=$ Kinerja Perusahaan pada perusahaan i pada periode ke $\mathrm{t}$, 
$\alpha \quad=$ Konstanta,

$B=$ Koefisien garis regresi,

$\mathrm{KI}_{\text {it }}=$ Komisaris independen pada perusahaan $\mathrm{i}$ pada periode $\mathrm{ke} \mathrm{t}$,

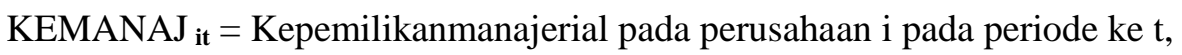

$\mathrm{PPP}_{\text {it }}=$ Persaingan pasar produk pada perusahaan $\mathrm{i}$ pada periode $\mathrm{ke} \mathrm{t}$,

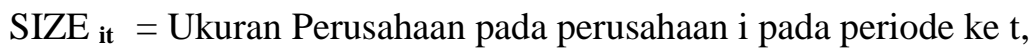

$\mathrm{LIQ}_{\text {it }}=$ Rasio lancar pada perusahaan $\mathrm{i}$ pada periode $\mathrm{ke} \mathrm{t}$,

e $=$ error.

\section{HASIL DAN PEMBAHASAN}

\section{Statistik Deskriptif}

Berikut ini merupakan hasil analisis statistik deskriptif :

Tabel 1

Hasil Analisis Statistik Deskriptif

\begin{tabular}{|l|r|r|r|r|r|}
\hline & \multicolumn{1}{|c|}{ N } & \multicolumn{1}{c|}{ Min } & \multicolumn{1}{c|}{ Max } & \multicolumn{1}{c|}{ Mean } & \multicolumn{1}{c|}{ Std. Deviation } \\
\hline KP & 711 & $-22,36$ & 37,68 & 8,28 & 9,62 \\
KI & 711 & 14,29 & 66,67 & 39,23 & 8,68 \\
KEMANAJ & 711 & 0,00 & 20,31 & 1,17 & 3,07 \\
PPP & 711 & 10,64 & 14,28 & 13,55 & 0,57 \\
SIZE & 711 & 21,79 & 31,97 & 27,90 & 1,75 \\
LIQ & 711 & 0,28 & 1403,01 & 208,71 & 164,21 \\
Valid N & 711 & & & & \\
(listwise) & & & & & \\
\hline
\end{tabular}

Sumber : Data sekunder yang diolah, 2019

Berdasarkan Tabel 1, Nilai rata-ratanya atau mean adalah 8,28 dengan deviasi standar 9,62 yang berarti terjadi perbedaan nilai Kinerja Perusahaan (KP) yang diteliti dengan nilai rata-ratanya yaitu sebesar 9,62. Nilai rata-rata Komisaris Independen (KI) yaitu 39,23 dengan deviasi standar 8,68 yang berarti terjadi perbedaan nilai Independensi Dewan Komisaris (INDEKOM) yang diteliti dengan nilai rata-ratanya yaitu sebesar 8,68. Hal ini menunjukkan bahwa kinerja perusahaan di Indonesia menunjukkan kinerja yang positif. Nilai terkecil variabel Komisaris Independen (KI) yaitu 14,29 yang merupakan nilai dari PT Total Bangun Persada Tbk dan yang tertinggi adalah 66,67 merupakan nilai dari PT Primarindo Asia I Tbk. Nilai terkecil variabel Kinerja Perusahaan (KP) adalah -22,36 ini adalah nilai PT Visi Media Asia Tbk dan yang tertinggi adalah 37,68, nilai dari PT Delta Djakarta Tbk. Dari statistic deskriptif dapat diketahui bahwa rata-rata perusahaan yang menjadi sampel penelitian telah memenuhi peraturan OJK No. 33 POJK.04/2014 yang menunjukkan angka diatas 30 persen. Nilai terkecil variabel Kepemilikan Manajerial (KEMANAJ) yaitu 0,000 dan yang tertinggi adalah 20,31 yang merupakan nilai PT Blue Bird Tbk. Skor rata-rata Kepemilikan Manajerial (KEMANAJ) yaitu 1,17 dengan deviasi standar 3,07 yang berarti terjadi perbedaan nilai Kepemilikan Manajerial (KEMANAJ) yang diteliti dengan nilai rata-ratanya yaitu sebesar 3,07. Dari statistic deskriptif tersebut dapat diketahui bahwa rata-rata kepemilikan manajerial yang ada di perusahaan public di Indonesia sangat kecil yaitu hanya 1,17 persen dari total kepemilikan saham perusahaan.

Nilai rata-rata Persaingan Pasar Produk (PPP) yaitu 11,06 dengan deviasi standar sebesar 13,55 yang berarti terjadi perbedaan nilai Persaingan Pasar Produk (PPP) yang diteliti dengan nilai rataratanya yaitu sebesar 13,55. Nilai terkecil variabel Persaingan Pasar Produk (PPP) yaitu 10,64. nilai dari PT Bumi Teknokultura Unggul Tbk dan yang tertinggi adalah 14,28, nilai dari PT Gudang Garam Tbk dan PT Wismilak Inti Makmur Tbk. Penelitian ini menggunakan Market size sebagai pengukuran persaingan pasar produk. Market size merupakan populasi pembeli dalam suatu pasar atau industri. Peningkatan volume permintaan mengarahkan pada adanya peningkatan market size, dan sebagai hasilnya meningkatkan persaingan di Industri dimana perusahaan beroperasi. Selama masih ada permintaan juga akan diperlukan insentif bagi perusahaan baru tersebut masuk ke pasar. 


\section{Pengujian Hipotesis}

Tabel 2

\section{Hasil Uji t Model 1}

Coefficients $^{\mathrm{a}}$

\begin{tabular}{|l|r|r|r|r|r|}
\hline \multirow{2}{*}{ Model } & \multicolumn{2}{|l|}{ Unstandardized Coefficients } & $\begin{array}{c}\text { Standardized } \\
\text { Coefficients }\end{array}$ & \multirow{2}{*}{$\mathrm{t}$} & Sig. \\
\cline { 2 - 4 } & \multicolumn{1}{|c|}{ B } & Std. Error & \multicolumn{1}{c|}{ Beta } & & \\
\hline \multirow{2}{*}{ (Constant) } & $-17,68$ & 4,07 & & $-7,53$ & 0,00 \\
KI & 0,05 & 0,04 & 0,04 & 0,12 & 0,90 \\
1 KEMANAJ & 0,29 & 0,12 & 0,08 & 2,48 & 0,01 \\
SIZE & 1,93 & 0,22 & 0,32 & 8,95 & 0,00 \\
LIQ & 0,09 & 0,02 & 0,150 & 4,23 & 0,00 \\
\hline
\end{tabular}

a. Dependent Variable: KP

Sumber : Data sekunder yang diolah, 2019

Tabel 2 hasil uji regresi berganda Uji t menunjukkan variabel KI memiliki koefisien beta sebesar 0,05 dan nilai signifikansi sebesar 0,90 yang lebih besar dari 0,05. Hal ini berarti variabel Komisaris Indepeden (KI) terbukti tidak berpengaruh secara signifikan terhadap variabel Kinerja Perusahaan (KP), maka dari itu hipotesis 1 ditolak. Variabel Kepemilikan Manajerial (KEMANAJ) memiliki koefisien beta sebesar 0,29 dan nilai signifikansi sebesar 0,01. Nilai signifikansi sebesar 0,01 lebih rendah dari 0,05, yang berarti variabel Kepemilikan Manajerial (KEMANAJ) terbukti berpengaruh positif signifikan terhadap variabel Kinerja Perusahaan (KP), maka dari itu hipotesis 2 diterima. Berdasarkan hasil regresi pada Tabel 4.13, variabel kontrol Ukuran Perusahaan (SIZE) diperoleh nilai signifikansi sebesar 0,00 yang lebih lecil dari 0,05. Pada kolom B didapati angka sebesar 1,93 yang berarti Ukuran Perusahaan (SIZE) berpengaruh positif signifkan terhadap Kinerja Perusahaan (KP). Hasil ini dapat disimpulkan bahwa semakin tinggi nilai Ukuran Perusahaan (SIZE) pada suatu perusahaan maka semakin tinggi tingkat Kinerja Perusahaan (KP) pada perusahaan tersebut.

Variabel kontrol Rasio Lancar (LIQ) menunjukkan hasil yang memiliki signifikansi sebesar $0,00<0,05$, Pada kolom B didapati angka sebesar 0,09, yang berarti Rasio Lancar (LIQ) berpengaruh positif terhadap Kinerja Perusahaan (KP). Hasil ini dapat disimpulkan bahwa semakin tinggi nilai Rasio Lancar (LIQ) pada suatu perusahaan maka semakin tinggi tingkat Kinerja Perusahaan (KP) pada perusahaan tersebut. Hasil pengujian dari variabel SIZE dan LIQ sesuai dengan penelitan ... yang menyatakan bahwa adanya kinerja yang lebih baik dari perusahaan mempunyai ukuran perusahaan yang lebih besar dan juga rasio likuiditas yang lebih tinggi dibanding perusahaan yang ukuran perusahaannya kecil dengan rasio likuiditas yang rendah.

Tabel 3

Hasil Uji t Model 2

Coefficients $^{\mathbf{a}}$

\begin{tabular}{|l|r|r|r|r|r|}
\hline \multirow{2}{*}{ Model } & \multicolumn{2}{|c|}{$\begin{array}{c}\text { Unstandardized } \\
\text { Coefficients }\end{array}$} & $\begin{array}{c}\text { Standardized } \\
\text { Coefficients }\end{array}$ & \multirow{2}{*}{ Sig. } \\
\cline { 2 - 4 } & \multicolumn{1}{|c|}{ B } & Std. Error & \multicolumn{1}{c|}{ Beta } & & \\
\hline (Constant) & $-31,11$ & 8,90 & & $-3,76$ & 0,00 \\
KI & 1,58 & 0,67 & 10,29 & 2,33 & 0,02 \\
KEMANAJ & $-1,74$ & 1,92 & $-0,51$ & $-0,90$ & 0,36 \\
PPP & 4,76 & 2,17 & 0,25 & 2,18 & 0,03 \\
KI.PPP & 0,18 & 0,08 & 1,32 & 2,33 & 0,02 \\
KEMANAJ.PPP & 0,24 & 0,22 & 0,61 & 1,07 & 0,03 \\
SIZE & 1,89 & 0,22 & 0,31 & 8,44 & 0,00 \\
LIQ & 0,01 & 0,02 & 0,14 & 4,06 & 0,00 \\
\hline
\end{tabular}

a. Dependent Variable: KP

Sumber : Data sekunder yang diolah, 2019 
Tabel 3 menunjukkan bahwa hasil pengujian pengaruh interaksi komisaris independen dan persaingan pasar produk (KI.PPP) terhadap kinerja perusahaan (KP) diperoleh nilai koefisien beta sebesar 0,18 dan nilai signifikansi sebesar 0,02. Nilai signifikansi sebesar 0,02 lebih rendah dari 0,05, yang berarti interaksi komisaris independen dan persaingan pasar produk (KI.PPP) memiliki pengaruh negatif signifikan terhadap KP, maka dari itu hipotesis 3 diterima. Hasil pengujian pengaruh interaksi kepemilikan manajerial dan persaingan pasar produk (KEMANAJ.PPP) terhadap kinerja perusahaan (KP) diperoleh nilai koefisien beta sebesar 0,24 dan nilai signifikansi sebesar 0,03. Nilai signifikansi sebesar 0,03 lebih rendah dari 0,05 , yang berarti interaksi persaingan pasar produk dan kepemilikan manajerial memiliki pengaruh positif signifikan terhadap kinerja perusaahaan, maka dari itu hipotesis 4 diterima.

Dari Tabel 4.16 tersebut, maka persamaan model regresi adalah sebagai berikut:

Model 1: $\mathrm{KP}_{\mathrm{it}}=\mathbf{- 1 7 , 6 8}+\mathbf{0 , 0 5} \mathrm{KI}_{\mathrm{it}}+\mathbf{0 , 2 9} \mathrm{KEMANAJ}_{\mathrm{it}}+\mathbf{1 , 9 3} \mathrm{SIZE}_{\mathrm{it}}+0,09 \mathrm{LIQ}_{\mathrm{it}}+\mathrm{e}$

Dari Tabel 4.16 tersebut, maka persamaan model regresi adalah sebagai berikut:

Model $2: \mathrm{KP}_{\mathrm{it}}=-31,11+1,58 \mathrm{KI}_{\mathrm{it}}-1,74 \mathrm{KEMANAJ}_{\mathrm{it}}+4,76 \mathrm{PPP}_{\mathrm{it}}+\mathbf{0 , 1 8} \mathrm{KI}_{\mathrm{it} .} \mathrm{PPP}_{\mathrm{it}}+\mathbf{0 , 2 4}$ KEMANAJ JitoPPP it $+1,89$ SIZE $_{i t}+0,01$ LIQ $_{i t}+e$

\section{Pengaruh Komisaris Independen terhadap Kinerja Perusahaan}

Hasil pengujian hipotesis menunjukkan tidak terdapat pengaruh komisaris independen terhadap kinerja perusahaan. Dapat diartikan semakin besar jumlah komisaris independen pada suatu perusahaan maka tidak akan berpengaruh pada kinerja perusahaan tersebut. Menurut Mardnly (2018) hal ini terjadi karena komisaris independen walaupun penting dalam meningkatkan kekuatan pengawasan dewan komisaris terhadap direksi terkait dengan kegiatan pengurusan perusahaan Namun diasumsikan dewan komisaris yang berasal dari luar perusahaan atau komisaris independen tidak memiliki kecenderungan untuk mempunyai kedekatan dengan direksi (Mardnly, 2018). Namun dalam beberapa penelitian menunjukkan jika komisaris yang berasal dari dalam perusahaan lebih baik dalam mengawasi direksi dibandingkan dengan komisaris independen (Moradi et al., 2017).

Alasan yang mendasari hal ini karena komisaris dari dalam perusahan lebih memberikan perhatiannya atau waspada terhadap kinerja operasi perusahaan (Singla \& Singh, 2019). Dapat dikatakan komisaris dari dalam perusahaan memiliki minat yang besar untuk menghapus ketidakefisiensi kinerja dari direksi jika dibandingkan dengan komisaris dari luar perusahaan atau komisaris independen yang mungkin memiliki jadwal yang padat (Karuna, 2020). Dalam penelitian ini, berdasarkan data statistik deskriptif rata-rata proporsi komisaris independen sebesar 39,23 persen (sudah melebihi batas minimal yang ditetapkan dalam Peraturan OJK No. 33 POJK.04/2014 yaitu sebesar 30 persen), akan tetapi hal ini tidak mempengaruhi kinerja perusahaan. Hasil penelitian ini sejalan dengan penelitian Mardnly (2018) yang menyatakan bahwa terdapat kemungkinan komisaris independen kalah suara pada saat dilakukan pengambilan suara untuk pengambilan suatu keputusan. Hal ini menyebabkan kualitas fungsi pengawasan dalam perusahaan akan sulit ditingkatkan dan mengganggu peningkatan kinerja perusahaan sehingga keberadaan komisaris independen tidak berpengaruh terhadap kinerja perusahaan (Singla \& Singh, 2019).

\section{Pengaruh Kepemilikan Manajerial terhadap Kinerja Perusahaan}

Hasil pengujian hipotesis menunjukkan bahwa kepemilikan manajerial mempunyai pengaruh positif signifikan terhadap kinerja perusahaan. Berdasarkan hasil uji tersebut dapat diartikan bahwa semakin besar jumlah kepemilikan manajerial pada suatu perusahaan maka akan berdampak pada semakin meningkatnya tingkat kinerja perusahaan pada perusahaan tersebut. Juga berdasarkan hasil statistic deskriptif diketahui bahwa rata-rata direksi memiliki kepemilikan saham perusahaan sebesar 1,17 persen dengan tingkat kepemilikan terbesar yaitu 20,31 persen. Hal ini menunjukkan kepemilikan manajerial rata-rata perusahaan cukup tinggi untuk mendorong manajemen meningkatkan kinerjanya.

Hasil penelitian ini sesuai dengan teori agensi. Berdasarkan teori agensi, menurut Jensen and Meckling (1976), kepemilikan saham perusahaan oleh manajemen dalam hal ini yaitu direksi akan menempatkan kepentingan investor searah dengan kepentingan dari manajemen. Hal ini dikarenakan dengan keterlibatan direksi dalam kepemilikan saham akan membuat direksi dapat bertindak sebagai pemilik perusahaan. Konflik kepentingan antara pemegang saham (pemilik perusahan) dan direksi sebagai pengelola perusahaan menjadi rendah karena direksi juga memiliki posisi sebagai pemegang saham. 
Peningkatan kepemilikan manajerial dapat digunakan sebagai cara untuk mengatasi masalah keagenan. Manajer akan termotivasi untuk meningkatkan kinerjanya yang juga merupakan keinginan dari para pemegang saham (Mardnly, 2018). Semakin besar proporsi kepemilikan saham pada perusahaan maka manajemen cenderung berusaha lebih giat untuk kepentingan pemegang saham yang tidak lain adalah dirinya sendiri. Menurut Farooque (2019) Kepemilikan manajerial akan membantu penyatuan kepentingan antara manajer dan pemegang saham, sehingga manajer ikut merasakan secara langsung manfaat dari keputusan yang diambil dan ikut pula menanggung kerugian sebagai konsekuensi dari pengambilan keputusan yang salah. Adanya rasa kepemilikan perusahaan akan menjadikan manajemen merasa menanggung konsekuensi dari keputusan yang diambil sehingga menjadikan mereka lebih berhati-hati dalam pengelolaan perusahaan (Moradi et al., 2017).

Menurut Sarpong-Danquah, Gyimah, Afriyie, \& Asiama (2018) dan Arora \& Sharma (2016) Dalam kerangka teori agensi, hubungan antara agent dan principal, direksi yang sekaligus sebagai pemegang saham akan meningkatkan kinerja perusahaan. Karena dengan meningkatnya kinerja perusahaan maka nilai kekayaannnya sendiri sebagai individu pemegang saham akan ikut meningkat pula. Dengan menjadi pemegang saham maka direksi akan membuat keputusan-keputusan yang bertujuan untuk meningkatkan kesejahteraan pemegang saham, dan berusaha mengoptimalkan penggunaan sumber daya yang dimiliki perusahaan yang nantinya hal ini akan berdampak pada peningkatan kinerja perusahaan. Hasil penelitian ini selaras dengan penelitian Farooque (2019), Aswathy Mohan \& S. Chandramohan (2018), Mardnly (2018), Moradi (2017) menunjukkan bahwa kepemilikan manajerial berpengaruh positif signifikan terhadap kinerja perusahaan.

\section{Pengaruh Persaingan Pasar Produk dalam Memoderasi Hubungan Antara Komisaris Independen terhadap Kinerja Perusahaan}

Hasil pengujian hipotesis menunjukkan bahwa persaingan pasar produk berpengaruh signifikan terhadap hubungan komisaris independen dengan kinerja perusahaan. Hasil penelitian tersebut menunjukkan bahwa semakin tinggi tingkat independensi Komisaris Independen yang dimoderasi dengan persaingan pasar produk, maka semakin tinggi pula kinerja perusahaan yang dicapai. Hal ini sejalan dengan teori kontingensi yang menyatakan kinerja sebuah organisasi selalu dipengaruhi oleh variabel kesesuaian antara variabel utama dengan variabel lain, atau sering disebut fit, terhadap kinerja (Venkatraman, 1989). Komisaris independen adalah dewan komisaris yang berasal dari luar perusahaan yang tidak memiliki hubungan afiliasi lain dengan perusahaan, dan tidak memiliki konflik kepentingan aktual dan potensial dengan perusahaan dimana komisaris independen tersebut bekerja (Moradi et al., 2017). Komisaris Independen memiliki insentif untuk mengembangkan reputasi sebagai ahli dalam pengendalian atau pengawasan keputusan yang berdiri untuk kepentingan pemegang saham secara objektif dan tidak memihak. Hal ini berarti secara efektif memantau perilaku direksi dan manajer (Karuna, 2020). Ketika proporsi komisaris independen meningkat, kemungkinan penipuan keuangan akan menurun dan mampu memberikan tuntutan kepada manajemen untuk mencapai kinerja perusahaan yang tinggi. Tingginya proporsi komisaris independen mengarah pada peningkatan kinerja yang lebih tinggi (Majeed et al., 2018). Dalam persaingan persaingan yang tinggi, perusahaan dengan tata kelola yang buruk meningkatkan kemungkinan digabung atau dilikuidasi, yang akan menyebabkan hilangnya utilitas manager dan hilangnya reputasi komisaris independen. Untuk menjaga reputasinya, komisaris independen termotivasi untuk lebih giat mengawasi perilaku manager atas pencapaian kinerja mereka yang nantiny akan meningkatkan kinerja perusahaan (Majeed et al., 2018).

Adapun menurut Moradi, Bagherpour Velashani, \& Omidfar (2017) kemampuan pengawasan yang efektif dari dewan komisaris akan membuat manajemen perusahaan melakukan kinerja operasional dengan lebih baik. Hal ini tentunya akan mempengaruhi kinerja keuangan perusahaan menjadi lebih baik. Menurut Liu (2018) persaingan dalam pasar produk adalah mekanisme yang sesuai dalam artian perusahaan-perusahaan yang berada dalam suatu industri akan saling bersaing satu sama lain untuk menjual produknya kepada konsumen. Perusahaan tersebut juga harus menyediakan produk yang sesuai dengan preferensi konsumen yang beragam terutama dalam hal penetapan harga jual. Hal ini bertujuan mendapatkan pangsa pasar yang diharapkan untuk menjual produknya tersebut. Dengan adanya mekanisme persaingan seperti itu memaksa komisaris independen semakin meningkatkan perannya dalam mengawasi dan mengarahkan para direksi yang berperan sebagai pengelola perusahaan untuk dapat mengoptimalkan pengalokasian sumber daya yang dimiliki perusaahan. Mekanisme persaingan tersebut akan mendorong perusahaan untuk dapat mengoptimalkan penerapan praktik tata 
kelola perusahaan terutama mengenai alokasi dan pengelolaan sumber daya yang dimiliki perusahaan agar perusahaan dapat beroperasi secara efisien (Karuna, 2020). Oleh karena itu, persaingan dapat memiliki pengaruh yang mendisiplinkan perilaku dan ketidakefektifan peran dari komisaris independen untuk melaksanakan fungsi pengawasannya secara optimal. Hasil penelitian ini sesuai dengan penelitian Moradi, Bagherpour Velashani, \& Omidfar (2017) yang menemukan adanya pengaruh positif dan signifikan interaksi komisaris independen dan persaingan pasar produk terhadap kinerja perusahaan. Hal ini menunjukkan bahwa efisiensi dan efektivitas dari mekanisme tata kelola perusahaan dapat meningkat bergantung pada tingkat persaingan pasar produk. Hasil penelitian ini juga sesuai Iqbal (2020) dengan penelitian yang menemukan bahwa perusahaan mengalami pertumbuhan produktivitas yang lebih tinggi saat mereka beroperasi dalam situasi pasar persaingan yang lebih tinggi dan diperoleh pertumbuhan produktivitas yang lebih tinggi. Dalam hal ini dampak keberadaan komisaris independen terhadap kinerja perusahaan lebih kuat ketika persaingan di pasar produk perusahaan ketat atau intens.

\section{Pengaruh Persaingan Pasar Produk dalam Memoderasi Hubungan Antara Kepemilikan Manajerial terhadap Kinerja Perusahaan}

Hasil pengujian hipotesis menunjukkan persaingan pasar produk berpengaruh signifikan terhadap hubungan komisaris independen dengan kinerja perusahaan. Berdasarkan hal tersebut dapat disimpulkan bahwa interaksi kepemilikan manajerial dan persaingan pasar produk (KEMANAJ.PPP) memiliki pengaruh positif signifikan terhadap kinerja perusaahaan. Hasil penelitian tersebut menunjukkan bahwa semakin tinggi tingkat kepemilikan manajerial yang dimoderasi dengan persaingan pasar produk, maka semakin tinggi kinerja.

Menurut teori kontingensi tidak ada cara terbaik dalam mencapai kesesuaian antara faktor organisasi dan lingkungan untuk memperoleh prestasi yang baik bagi suatu organisasi. Proposisi dalam teori ini adalah bahwa kinerja perusahaan merupakan konsekuensi fit atau match atau ke-pas-an antara dua atau lebih faktor. Berdasarkan hasil penelitian terdahulu yang telah diuraikan menunjukkan hasil penelitian terkait kepemilikan manajerial dan kinerja perusahaan menunjukkan hasil yang tidak konsisten (Moradi et al., 2017). Perbedaan hasil penelitian terjadi karena masih terdapat faktor lain yang dapat memperkuat efektifitas mekanisme tata kelola perusahaan berupa kepemilikan manajerial dalam mencapai kinerja yang tinggi. Faktor tersebut adalah persaingan pasar produk. Pemilihan variabel persaingan pasar produk didasarkan pada basis teori kontingensi yang menyatakan bahwa hubungan dua atau lebih faktor sangat bergantung pada faktor lain (kontinguen) yang tidak bisa dikontrol oleh suatu organisasi (Venkatraman, 1989).

Menurut Persaingan pasar produk memoderasi hubungan antara dua faktor (mekanisme tata kelola perusahaan dan kinerja perusahaan). Argumentasi ini selaras dengan pandangan yang menyimpulkan bahwa lingkungan merupakan faktor kontekstual penting yang mempunyai dampak sangat kuat terhadap arah strategi perusahaan (Majeed et al., 2018). Persaingan pasar produk merupakan salah satu faktor yang terkait dengan lingkungan industri perusahaan, yang secara langsung mempengaruhi perusahaan dan tindakan kompetitifnya (Liu et al., 2018). Jadi penelitian yang akan dilakukan adalah memprediksi bahwa hubungan kepemilikan manajerial dengan kinerja perusahaan secara keseluruhan juga tergantung pada bagaimana mekanisme tata kelola perusahaan tersebut berada pada kondisi persaingan yang dihadapi (Moradi et al., 2017). Sebagai bagian dari mekanisme tata kelola perusahaan, kepemilikan saham oleh manajemen dapat mempengaruhi bagaimana perusahaan dikelola dan dikendalikan. Menurut Jensen and Meckling (1976), kepemilikan saham perusahaan oleh manajemen akan menempatkan kepentingan investor searah dengan kepentingan dari manajemen. Hal ini dikarenakan dengan keterlibatan manajemen dalam kepemilikan saham akan membuat manajemen dapat bertindak sebagai pemilik perusahaan. Hal ini sesuai dengan teori agensi yang menyatakan bahwa kepemilikan saham perusahaan oleh manajemen akan menempatkan kepentingan investor searah dengan kepentingan dari manajemen.

Menurut Liu et al (2018) secara mandiri interaksi antara persaingan pasar produk dan mekanisme tata kelola perusahaan dapat membatasi kebijaksanaan manajerial atas keputusan-keputusan yang diambil oleh pihak manajemen atau mendorong manajer atau orang dalam agar selaras dengan kepentingan pemegang saham. Pada saat yang sama mungkin interaksi antara persaingan pasar produk dan mekanisme tata kelola perusahaan dapat saling melengkapi atau hubungan substitusi antara variabel yang berbeda (Teng \& Li, 2011). Secara khusus, persaingan dan indikator tata kelola perusahaan dapat bersama-sama bergerak ke arah yang sama atau ke dalam arah yang berlawanan dan memengaruhi 
kinerja perusahaan. Ketika interaksi bergerak ke arah yang sama atau berlawanan, dapat dikatakan interaksi keduanya saling melengkapi atau menggantikan. Menurut Karuna (2020) Persaingan pasar produk membatasi keleluasaan manajerial dan karenanya bertindak sebagai mekanisme alternatif untuk perangkat tata kelola perusahaan lainnya. Persaingan pasar produk juga dapat memperkuat kekuatan pasar tertentu. Misalnya saja persaingan yang lebih tinggi dapat mengurangi laba perusahaan, sehingga mengikis nilai pasar saham. Itu mungkin menandakan suatu pengambilalihan perusahaan sehingga memberi tekanan pada manajer untuk berkinerja lebih baik. Ketika perangkat saling melengkapi, dampaknya persaingan pasar produk akan lebih besar pada perusahaan dengan struktur tata kelola yang efisien. Efek substitusi menyiratkan bahwa ketika tata kelola perusahaan lemah, Persaingan berperan penting sebagai perangkat disipliner yang memaksa manajer untuk meningkatkan kinerja dan mengurangi kelonggaran manajerial. Di sisi lain, jika kompetisi dan tata kelola perusahaan adalah pelengkap, persaingan pasar produk mungkin tidak cukup sendirian untuk mengurangi ketidakefisienan produktif dalam suatu lingkungan dengan tata kelola perusahaan yang buruk.

Bukti empiris dan studi teoritis menunjukkan bahwa persaingan memiliki pengaruh positif terhadap produktivitas perusahaan. Persaingan dalam pasar produk perusahaan adalah kekuatan yang sangat berpengaruh untuk memastikan pelaksanaan tata kelola perusahaan yang baik. Bahkan ketika dihadapkan pada tata kelola internal yang lemah, persaingan pasar produk yang tinggi dapat memastikan bahwa manajemen tidak lalai. Persaingan memberikan tolok ukur untuk mengukur kinerja manajer. Persaingan pasar produk yang lebih tinggi memaksa para manajer untuk fokus mencapai kinerja yang tinggi, karena jika tidak, pada akhirnya akan mengakibatkan kebangkrutan dan penutupan perusahaan (Singla \& Singh, 2019). Meningkatnya kemungkinan kebangkrutan, persaingan mendorong manager untuk melakukan upaya yang lebih besar yang memungkinkan pengurangan biaya yang diperlukan untuk menghindari kebangkrutan. Selain itu, persaingan memiliki implikasi reputasi yang parah. Karena kinerja perusahaan akan dibandingkan dengan rekan-rekannya, itu menempatkan banyak tekanan moral terhadap manager untuk mencapai kinerja perusahaan yang tinggi.

Manajer yang memiliki saham perusahaan maka manajemen akan membuat keputusan dan bertindak dengan tujuan meningkatkan kesejahteraan bagi pemegang saham perusahaan yang tidak lain adalah dirinya sendiri, yang nantinya hal ini berpengaruh terhadap kinerja perusahaan. Adanya rasa kepemilikan perusahaan menjadikan manajemen merasa menanggung konsekuensi dari keputusan yang diambil sehingga menjadikan mereka lebih berhati-hati dalam pengelolaan perusahaan. Kepemilikan saham atas perusahaan, manajemen akan merasa bahwa pencapaian yang diharapkan investor atau kepentingan investor dapat selaras dengan kepentingan manajemen (Moradi et al., 2017).

Kepemilikan manajerial menyebabkan berkurangnya tindakan opportunistik manajemen untuk memaksimalkan kepentingan pribadinya. Manajemen perusahaan akan mengambil tindakan dan keputusan yang sesuai dengan kepentingan perusahaan (Iqbal et al., 2020). Hal ini dilakukan karena selain berperan sebagai pengelola, manajemen yang memiliki saham perusahaan juga bertindak sebagai pemilik perusahaan. Tindakan ini diperkuat dengan adanya persaingan pasar produk yang menuntut manajemen untuk dapat beroperasi secara efisien. Perusahaan-perusahaan yang berada dalam suatu industri akan saling bersaing satu sama lain untuk menjual produknya kepada konsumen. Perusahaan tersebut juga harus menyediakan produk yang sesuai dengan preferensi konsumen yang beragam terutama dalam hal penetapan harga jual untuk mendapatkan pangsa pasar yang diinginkan (Moradi et al., 2017).

Adanya mekanisme persaingan seperti yang diuraikan diatas, maka manajemen sebagai pengelola perusahaan dalam proses produksinya harus mengoptimalkan pengalokasian sumber daya yang dimiliki perusahaan agar dapat beroperasi secara efisien. Dalam situasi persaingan tersebut manajemen yang selaku pengelola juga sekaligus pemilik perusahaan akan terdorong untuk mengoptimalkan penerapan praktik tata kelola perusahaan untuk mencapai kinerja yang diharapkan. Oleh karena itu, persaingan dapat memiliki pengaruh yang mendisiplinkan perilaku dan ketidakefektifan peran dari manajemen dalam menjalankan fungsinya sebagai pihak yang mengelola perusahaan (Moradi et al., 2017). Jadi dampak kepemilikan manajerial terhadap kinerja perusahaan lebih kuat ketika persaingan di pasar produk perusahaan ketat.

Sesuai dengan teori kontingensi, kinerja sebuah organisasi selalu dipengaruhi oleh variabel kesesuaian antara variabel utama dengan variabel lain, atau sering disebut fit, terhadap kinerja (Venkatraman, 1988). Keterlibatan direksi dalam kepemilikan saham menjadikan konflik kepentingan pemegang saham dan direksi sebagai pengelola perusahaan menjadi lebih rendah. Hal ini karena direksi 
juga mempunyai posisi sebagai pemegang saham. Hal ini juga sesuai dengan teori agensi yang menyatakan bahwa manajemen yang memiliki saham perusahaan maka manajemen akan membuat keputusan-keputusan dan bertindak dengan tujuan meningkatkan kesejahteran bagi pemegang saham perusahaan, nantinya ini berdampak terhadap kinerja perusahaan (Moradi et al., 2017).

Kesulitan pemilik melakukan monitoring terhadap manajemen dalam dinamika ketidak-pastian lingkungan yang tinggi memberikan keleluasan manajerial yang lebih tinggi bagi para manajer. Oleh karena itu kepemilikan perusahaan oleh manajemen sebagai bentuk atau wujud sistem monitoring terhadap manajemen yang dilakukan oleh pemilik sangat tergantung pada posisi persaingan pasar perusahaan itu sendiri (Iqbal et al., 2020). Semakin tinggi persaingan pasar produk, semakin tinggi pula keleluasan manajerial. Apabila manajemen dengan keleluasaan manajerial tinggi ini diberikan kesempatanuntuk berfungsi sebagai pemilik, maka keleluasaan manajerial ini akan dijalankan sesuai dengan kepentingan pemilik luar (Karuna, 2020). Dengan kata lain kepemilikan oleh manajemen dalam situasi persaingan yang tinggi sangat produktif bagi kinerja perusahaan secara keseluruhan. Adapun menurut Teng \& Li (2011) persaingan pasar produk membatasi keleluasaan manajerial dan karenanya bertindak sebagai mekanisme alternatif untuk perangkat tata kelola perusahaan lainnya.Persaingan pasar produk juga dapat memperkuat kekuatan pasar tertentu. Misalnya saja persaingan yang lebih tinggi dapat mengurangi laba perusahaan, sehingga mengikis nilai pasar saham. Itu mungkin menandakan suatu pengambilalihan perusahaan sehingga memberi tekanan pada manajer untuk berkinerja lebih baik. Menurut Liu, Qu, \& Haman (2018) dan Moradi, Bagherpour Velashani, \& Omidfar (2017) ketika perangkat saling melengkapi, dampaknya persaingan pasar produk akan lebih besar pada perusahaan dengan struktur tata kelola yang efisien. meneliti pengaruh dari persaingan pasar produk, pengendalian pemegang saham terhadap pertumbuhan efisiensi perusahaan di Inggris. Hasil penelitian tersebut menunjukkan adanya pengaruh positif dari persaingan pasar produk dan pengendalian pemegang saham terhadap peningkatan pertumbuhan produktivitas.

\section{KESIMPULAN}

Penelitian ini menguji empat hipotesis dengan menguji dan menganalisis pengaruh mekanisme tata kelola perusahaan terhadap kinerja perusahaan serta pengaruh interaksi mekanisme tata kelola perusahaan dan persaingan pasar produk terhadap kinerja perusahaan. Berikut merupakan kesimpulan yang diperoleh berdasarkan hasil penelitian yang dilakukan. Berkaitan dengan H1 yang menyatakan bahwa Komisaris independen mempunyai pengaruh positif signifikan terhadap kinerja perusahaan. Hasil pengujian $\mathrm{H} 1$ menunjukkan bahwa Komisaris independen tidak berpengaruh signifikan terhadap kinerja perusahaan sehingga $\mathrm{H} 1$ ditolak. Berkaitan dengan $\mathrm{H} 2$ yang menyatakan bahwa kepemilikan manajerial berpengaruh positif signifikan terhadap kinerja perusahaaan hasil pengujian menunjukkan bahwa kepemilikan manajerial berpengaruh positif signifikan terhadap kinerja perusahaaan. Hasil pengujian $\mathrm{H} 3$ yang menyatakan bahawa Persaingan pasar produk berpengaruh signifikan terhadap hubungan komisaris independen dan kinerja perusahaan serta $\mathrm{H} 4$ yang menyatakan Persaingan pasar produk berpengaruh signifikan terhadap hubungan kepemilikan manajerial dan kinerja perusahaan hasil pengujian mendukung hipotesis. Interaksi antara komisaris independen dengan persaingan pasar produk dan interaksi antara kepemilikan manajerial mampu meningkatkan kinerja perusahaan. Pengaruh komisaris independen dan kepemilikan manajerial terhadap kinerja perusahaan menjadi lebih kuat dengan adanya persaingan yang kuat di pasar produk dimana perusahaan beroperasi. Secara umum hasil penelitian mendukung hipotesis yang ada. Keterbatasan penelitian ini yaitu hanya menggunakan dua ukuran mekanisme internal tata kelola perusahaan serta hasil penelitian menunjukkan Adjusted $\mathrm{R}$ square yang rendah. Hal ini menjelaskan bahwa kemampuan variabel komisaris independen dan kepemilikan manajerial dan interaksi antara persaingan pasar produk dan mekanisme tata kelola perusahaan terhadap kinerja perusahaan adalah lemah.

\section{SARAN:}

1. Saran Teoritis pada penelitian ini seharusnya menggunakan proksi persaingan pasar produk pada level perusahaan misalnya menggunakan IPCM (Industry Adjusted Price Cost Margin), bukan pada level industri sehingga penelitian lebih spesifik, tidak menyeluruh dan lebih fokus.

2. Saran Praktis pada penelitian ini, investor harus dapat mengatur atau memberikan sanksi yang sangat tegas berupa teguran ataupun pemecatan kepada komisaris independen untuk 
meningkatkan perannya dalam mengawasi dan mengarahkan para direksi agar mengoptimalkan pengalokasian sumber daya yang dimiliki perusaahan sehingga perusahaan dapat berioperasi secara efisien dan tidak kalah saing. Perusahaan sebaiknya juga meningkatkan jumlah persentase kepemilikan manajerial mengingat manajemen yang bertindak sebagai pengelola dan juga sekaligus pemilik perusahaan akan terdorong untuk mengoptimalkan penerapan praktik tata kelola perusahaan dalam mencapai kinerja yang diharapkan pemilik yaitu dirinya sendiri.

\section{REFERENSI}

Arora, A., \& Sharma, C. (2016). Corporate governance and firm performance in developing countries: evidence from India. Corporate Governance (Bingley), 16(2), 420-436. https://doi.org/10.1108/CG-01-2016-0018

Aswathy Mohan \& S. Chandramohan. (2018). Impact of Corporate Governance on Firm Performance: Empirical Evidence From India. IMPACT: International Journal of Research in Humanities, Arts and Literature (IMPACT: IJRHAL), 6(2), 209-218. Diambil dari http://www.impactjournals.us/archives.php?year=2018_11_2\&id=11\&jtype=2\&page=6

Azeez, D. A. A. (2015). Corporate Governance and Firm Performance: Evidence from Sri Lanka. Journal of Finance and Bank Management, 3(1). https://doi.org/10.15640/jfbm.v3n1a16

Farooque, O. Al. (2019). Board, audit committee, ownership and fi nancial performance - emerging trends from Thailand. 54-81. https://doi.org/10.1108/PAR-10-2018-0079

Iqbal, A., Zhang, X., Tauni, M. Z., \& Jebran, K. (2020). Principal-principal agency conflicts, product market competition and corporate payout policy in China. Journal of Asia Business Studies, 14(3), 265-279. https://doi.org/10.1108/JABS-02-2018-0038

Karuna, C. (2020). Product Market Competition and Managerial Pay. (April). https://doi.org/10.2308/jmar-52503

KNKG. (2006). Pedoman Umum Good Corporate Governance Indonesia.

Liu, L., Qu, W., \& Haman, J. (2018). Product market competition, state-ownership, corporate governance and firm performance. Asian Review of Accounting, 26(1), 62-83. https://doi.org/10.1108/ARA-05-2017-0080

Majeed, M. A., Yan, C., \& Tauni, M. Z. (2018). How does competition shape managerial decisions? Product market competition and financial statement comparability. Management Decision, 56(11), 2437-2471. https://doi.org/10.1108/MD-04-2017-0319

Mardnly, Z. (2018). Corporate governance and fi rm performance : an empirical evidence from Syria. 11(4), 591-607. https://doi.org/10.1108/IMEFM-05-2017-0107

Moradi, M., Bagherpour Velashani, M. A., \& Omidfar, M. (2017). Corporate governance, product market competition and firm performance: evidence from Iran. Humanomics, 33(1), 38-55. https://doi.org/10.1108/H-10-2016-0075

Puni, A., \& Anlesinya, A. (2020). Corporate governance mechanisms and fi rm performance in a developing country. 62(2), 147-169. https://doi.org/10.1108/IJLMA-03-2019-0076

Sarpong-Danquah, B., Gyimah, P., Afriyie, R. O., \& Asiama, A. (2018). Corporate Governance and Firm Performance: An Empirical Analysis of Manufacturing Listed Firms in Ghana. Accounting and Finance Research, 7(3), 111. https://doi.org/10.5430/afr.v7n3p111

Singla, M., \& Singh, S. (2019). Board monitoring, product market competition and firm performance. International Journal of Organizational Analysis, 27(4), 1036-1052. https://doi.org/10.1108/IJOA-07-2018-1482

Teng, M., \& Li, C. (2011). Product Market Competition, Board Structure, and Disclosure Quality. 5(2), 291-316. https://doi.org/10.1007/s11782-011-0132-5

Venkatraman, N. (1989). The Concept of Fit in Strategy Research: Toward Verbal and Statistical Correspondence. Academy of Management Review, 14(3), 423-444. https://doi.org/10.5465/amr.1989.4279078 